\title{
PENGARUH PENYAJIAN LAPORAN KEUANGAN DAERAH DAN AKSESIBILITAS TERHADAP PENGGUNAAN INFORMASI KEUANGAN DI KABUPATEN ALOR
}

\author{
Indryani Malaum ${ }^{1)}$; Rahmat Laan $^{2)}$; Akbar Yusuf ${ }^{3)}$ \\ ${ }^{1)}$ Alumnus Program Studi Akuntansi Universitas Muhammadiyah Kupang \\ ${ }^{2)}$ Program Studi Manajemen Universitas Muhammadiyah Kupang \\ ${ }^{3)}$ Program Studi Akuntansi Universitas Muhammadiyah Kupang
}

\begin{abstract}
ABSTRAKSI
Tujuan penelitian adalah untuk menguji Pengaruh penyajian laporan keuangan daerah terhadap penggunaan informasi keuangan daerah dan Pengaruh aksesibilitas terhadap penggunaan informasi keuangan daerah. Penelitian ini dilakukan di Kota Kalabahi Kabupaten Alor. Penelitian ini menggunakan jenis penelitian kuantitatif. Sumber data dalam penelitian ini adalah menggunakan data primer yang diperoleh dari hasil penyebaran kuesioner. Kuesioner dalam penelitian ini ditujukan kepada para pengguna informasi laporan keuangan daerah di Kabupaten Alor dengan menggunakan responden dari anggota DPRD,anggota Inspektorat Daerah, dan Masyarakat dalam hal ini Lembaga Suadaya Masyarakat (Yayasan Lendola). Dengan menggunakan metode populasi sampel. Jumlah sampel dalam penelitian ini adalah sebayak 56 orang. Dalam penelitian ini data dianalisis dengan menggunakan persamaan structural equation modelling (SEM) dengan pendekatan metode Partial Least Square (PLS). Hasil penelitian menunjukan bahwa Penyajian laporan keuangan daerah secara signifikan berpengaruh positif terhadap penggunaan informasi keuangan daerah dan aksesibilitas berpengaruh positif dan signifikan terhadap penggunaan informasi keuangan daerah.
\end{abstract}

Kata kunci: Penyajian laporan keuangan daerah, aksesibilitas, informasi keuangan daerah.

\section{A. PENDAHULUAN}

Informasi keuangan yang dilaporkan oleh pemerintah daerah menuntut adanya transparasi dan akuntabilitas. Untuk dapat meningkatkan transparasi dan akuntabilitas pengelolaan keuangan negara. Penggunaan informasi keuangan daerah penting diakukan karena para pengguna data mengetahui kondisi keuangan suatu daerah dengan melakukan berbagai analisis. Dengan melakukan reformasi dalam penyajian laporan keuangan, pemerintahan harus bisa menyediakan semua informasi keuangan yang relevan secara jujur dan terbuka kepada publik, karena kegiatan pemerintah adalah dalam rangka melaksanakan amanat rakyat (Mulyana, 2006) dalam Bandariy (2011).

Akuntabilitas adalah prinsip pertanggungjawaban publik kepada masyarakat, yang berarti bahwa proses penganggaran mulai dari perencanaan, penyusunan dan pelaksanaan harus benar-benar bisa dilaporkan dan dipertanggungjawabkan kepada DPRD dan masyarakat. Akuntabilitas masyarakatkan terhadap pengambilan keputusan berpengaruh sesuai dengan mandat yang diterimanya. Dalam hal ini, perumusan kebijakan yang dilakukan oleh pemerintah harus dapat diakses dan dikomunikasikan secara vertikal maupun horizontal dengan baik. Mardiasmo (2002).

Berdasarkan Peraturan Pemerintah Nomor 58 Tahun 2005 tentang Pengelolaan Keuangan Daerah, yang akuntabel dan transparan, pemerintah daerah wajib 
menyampaikan laporan pertanggungjawaban berupa Laporan Realisasi Anggaran, Neraca, Laporan Arus Kas, dan Catatan Atas Laporan Keuangan. Pertanggungjawaban ini tidak haya wajib disampakikan kepada lembaga legislatif tetapi juga harus disampaikan kepada masyaraka.

Laporan keuagan daerah Kabupaten Alor saat ini sangat penting bagi setiap masyarakt yang membutuhkan baik internal maupun eksternal sehingga dapat mengakibatkan kurangannya penggunaan penyajian laporan keuangan dan aksesibilitas terhadapat penggunaan informasi keuangan. Kurangnya pertanggungjawaban Pemerintah daerah dalam memberikan informasi keuangan mengakibatkan masyarakat tidak dapat mengakses laporan keuangan dengan mudah, hal ini dikarenakan banyak laporan tahunan yang tidak memuat semua informasi relevan yang dibutuhkan para pengguna laporan keuangan dan mengakibatkan laporan keuangan yang tidak lengkap sehingga dapat menurunkan kualitas dari akuntabiltas laporan keuangan daerah Kabupaten Alor.

Laporan keuangan daerah Kabupaten Alor sangat berpengaruh kepada keterbukaan transparansi dan aksesibilitas terhadap pengunaan informasi keuangan daerah. Oleh karena itu sangat penting untuk diteliti mengingat transparansi dan akuntabilitas dalam pengelolaan keuangan Daerah Kabupaten Alor yang diindentifikasikan melalui beberapa pentingnya penggunaan informasi keuangan daerah tersebut berimbas kepada kepercayaan publik terhadap kinerja Pemerintahan daerah Kabupaten Alor serta peraturan Pemerintah yang mewajibkan penyajian laporan keuangan secara lengkap dan mudah diakses oleh publik.

Berdasarkan penjelasan diatas, maka peneliti tertarik untuk melakukan suatu penelitian dengan judul "Pengaruh Penyajian Laporan Keuangan Daerah dan Aksesibilitas Terhadap Penggunaan Informasi Keuangan Daerah di Kabupaten Alor"

\section{B. Review Literatur Dan Pengembangan Hipotesis}

Beberapa teori yang digunakan dalam menjawab tujuan studi ini adalah Informasi Keuangan Daerah yang di pengaruhi oleh Penyajian Laporan Keuangan Derah dan Aksesibilitas.

\section{Hubungan Penyajian Laporan Keuangan Daerah dengan Penggunaan Informasi Keuangan Daerah}

Aliyah dan Aida, (2012) menyatakan bahwa Penggunaan informasi keuangan daerah berkaitan dengan penilaian para pengguna laporan keuangan daerah terhadap akuntabilitas dan transparansi setiap laporan keuangan yang disajikan oleh pemerinah daerah. Akuntabilitas dan transparansi keuangan daerah adalah pertanggungjawaban pemerintahan daerah berkenaan dengan pengelolaan keuangan daerah kepada publik secara terbuka dan jujur melalui media berupa penyajian laporan keuangan yang dapat diakses oleh berbagai pihak yang berkepentingan dengan anggapan bahwa publik berhak mengetahui informasi tersebut Aliyah dan Aida (2012). Penggunaan informasi keuangan daerah penting dilakukan karena para pengguna dapat mengetahui kondisi keuangan suatu daerah dengan melakukan berbagai analisis.

Fungsi laporan keuangan daerah yaitu untuk menyajikan informasi posisi keuangan, realisasi anggaran, arus kas, dan informasi-informasi terkait lainnya sebagai alat ukur kinerja manajemen di pemerintah daerah yang kemudian dinilai oleh pengguna 
informasi laporan keuangan. Pertanggungjawaban perlu dilakukan melalui media yang selanjutnya dapat dikomunikasikan kepada pihak internal maupun eksternal (publik) sebagai suatu kewajiban hukum dan bukan secara sukarela. Hasil feedback dari pengguna informasi atas penyajian laporan keuangan inilah yang kemudian menjadi bahan koreksi bagi pemerintah daerah atas kinerja mereka selama tahun anggaran berlangsung Rohaydi, 2013. Oleh karena itu laporan keuangan yang disusun pemerintah harus relevan, andal, dapat dibandingkan, dapat dipahami (PP No. 71 Tahun 2010) dan mengungkapkan secara lengkap sesuai dengan peraturan yang ada dan syarat-syarat agar laporan keuangan yang disajikan dapat memenuhi harapan pengguna.

Laporan keuangan juga bermanfaat dalam pemilihan program yang efektif dan ekonomis serta untuk penilaian investasi karena pemilihan program yang tepat sasaran, efektif dan ekonomis akan sangat membantu dalam proses penganggaran Sande (2013). Laporan keuangan yang disusun oleh pemerintah (pusat dan daerah) adalah bentuk pertanggungjawaban pemerintah terhadap penggunaan laporan keuangan berkenaan dengan pengelolaan keuangan daerah kepada publik secara transparan dan akuntabel serta dapat diakses oleh semua pihak yang membutuhkan dengan anggapan bahwa publik berhak mengetahui informasi laporan keuangan tersebut. Pemberlakuan PP No 58 tahun 2005 tentang pengelolaan keuangan daerah sebagai pengganti PP No 105 tahun 2000 yang mewajibkan penyampaian pertanggungjawaban berupa Laporan Realisasi Anggaran, Neraca daerah, Laporan Arus Kas, dan Catatan Atas Laporan Keuangan tersebut. Hal ini menjadi masalah tersendiribagi beberapa pemerintah daerah karena sistem dan pelaporan yang selama ini ada belum kondusif kearah tersebut (Mulyana (2006).

Bandary (2011), ketidakmampuan laporan keuangan dalam melaksanakan akuntabilitas tidak saja disebabkan karena laporan tahunan yang tidak memuat semua informasi relevan yang dibutuhkan para pengguna, tetapi juga karena laporan tersebut tidak dapat secara langsung tersedia dan aksesibel pada para pengguna potensial. Sebagai konsekuensinya, penyajian laporan keuangan yang tidak lengkap dan tidak aksesibel berimbas pada ketertarikan pengguna informasi yang ada secara optimal.

\section{Hubungan Aksesibilitas Laporan Keuangan dengan Penggunaan Informasi Keuangan Daerah}

Bandary (2011)laporan keuangan pemerintahan bermanfaat untuk menilai akuntabilitas. Melalui penyajian laporan keuangan para pengguna dapat melihat bagaimana pemerintah memilih kewajibannya untuk menjadi akuntabel secara publik. Disamping untuk menjadi akuntabilitas, laporan keuangan pemerintah memuat informasi akuntansi yang berguna sebagai bahan pertimbangan dalam pengambilan keputusan, terutama dalam melakukan alokasi sumber daya. Para pengguna laporan yang mempunyai keterbatasan kemampuan atau sumber daya dapat menyandarkan informasi keuangan pada laporan keuangan.informasi ini nantinya akan digunakan sebagai bahan pertimbangan dalam pengambilan keputusan.

Ketidakmampuan laporan keuangan dalam melaksanakan akuntabilias, tidak hanya disebabkan karena laporan tahunan yang tidak memuat semua informasi yang relevan yang dibutuhkan para pengguna, tetapi juga karena laporan tersebut tidak dapat secara langsung tersedia dan aksesibilitas pada pengguna potensial (Jones et al.,1985 dalam Mulyana 2006). Oleh karena itu, pemerintah daerah mendapat motivasi agar 
mampu menyajikan laporan keuangan tidak hanya kepada DPRD tetapi juga harus menyajikan fasilitas kepada masyarakat berupa kemudahan dalam mengetahui atau memperoleh informasi laporan keuangan.

Sesuai Standar Akuntansi Pemerintah dan Permendari Nomor 13 Tahun 2006 tentang Pengelolaan Keuangan Daerah, setiap akhir tahun periode anggaran Pemerintah Daerah diwajibkan untuk menyajikan Laporan Keuangan pokok yang terdiri dari Laporan Realisasi Anggaran, Neraca, Laporan Arus Kas, dan Catatan atas Laporan Keuangan yang dilampiri dengan Laporan Kinerja Keuangan serta ikhtisari Laporan Keuangan BUMD. Tuntutan pemerintah pusat yang mengharuskan setiap pelaporan keuangan pemerintah daerah harus terdapat Penyajian Laporan Keuangan Daerah hal ini diharapkan dapat berpengaruh positif terhadap penggunaan informasi keuangan daerah. Aksesibilitas laporan keuangan merupakan sarana penunjag dalam rangka perwujudan lembaga pemerintah daerah sebagai lembaga sektor publik. Aksesibilitas juga akan berpengaruh terhadap seberapa besar penggunaan informasi keuangan daerah.

Dari uraian di atas menunjukkan bahwa pengaruh penyajian laporan keuangan daerah dan aksesibimitas terhadap penggunaan informasi keuangan daerah di Kabupaten Alor adalah sebagai berikut:

H1 : penyajian laporan keuangan daerah berpengaruh positif terhadap penggunaan informasi keuangan daerah.

$\mathrm{H} 2$ : Aksesibilitas laporan kuangan daerah berpengaruh positif terhadap informasi keuangan daerah.

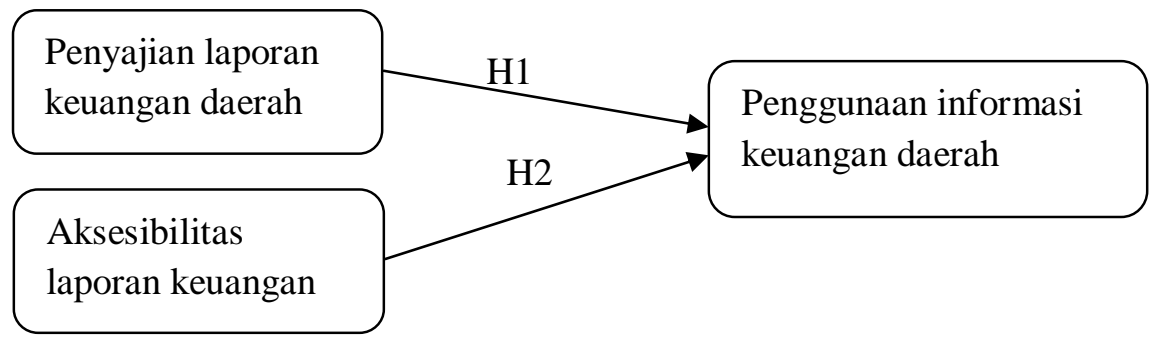

Gambar 1: Kerangka Pemikiran (Sumber: Olahan Penulis, 2018)

\section{METODE PENELITIAN}

\section{Desain Penelitian}

Dalam penelitian ini analisi data menggunakan model Structural Equation Modeling (SEM) dengan pendekatan Partial Least Squares (PLS). Alasan yang mendasari penggunaan PLS ini karena penelitian ini menggunakan 27 konstruk untuk mengukur komponen-komponen model intelektual. Penggunaan PLS bertujuan untuk menangkap konstruk-konstruk tersebut mana yang peling mempengaruhi masing-masing variabel penelitian ini. Dalam analisis dengan PLS, ada 2 hal yang dilakukan. Pertama, menilai outer model atau measurement model yakni penilaian terhadap reliabilitas dan validitas variabel penelitian. Ada tiga keriteria untuk menilai outer model yaitu: convergent validity, discriminant validity dan composite reliability. Kedua, menilai inner model atau structural model. Pengujian inner model atau model struktural dilakukan untuk melihat hubungan antara konstruk, nilai signifikansi dan R-square dari model penelitian. 


\section{Populasi dan Sampel}

Populasi dalam penelitian ini adalah penggunaan eksternal laporan keuangan pemerintah daerah kabupaten Alor, yaitu anggorta DPRD, pegawai Badan Pengawas Daerah (Bawasda) atau Inspektorat Daerah dan Masyarakat. Sampel dipilih berdasarkan metode purposive sampling.

\section{Teknik Pengumpulan Data dan Variabel}

Pengumpulan data intelektual laporan keuangan daerah di Kabupaten Alor menggunakan koesioner yang dikembangkan oleh Peggy Sande pada tahun 2013, yang mulanya digunakan dalam penelitiannya di Sumatra Barat. Data dikumpulkan melalui metode angket, yaitu menyebarkan daftar pernyataan (kuesioner) yang diisi atau dijawab oleh responden yakni Anggota DPRD, pegawai Inspektorat dan Masyarakat Kabupaten Alor dalam hal ini LSM (Yayasan Lendola). "Kuesioner merupakan teknik pengumpulan data yang dilakukan dengan cara memberi seperangkat pertanyaan atau pernyataan tertulis kepada responden untuk dijawabnya.." (Sugiyono, 2011: 192). Untuk memperoleh data yang sebenarnya kuesioner dibagikan secara langsung kepada responden, yaitu dengan mendatangi tempat responden.

\section{Teknik Analisism Data}

Pengujian hipotesis penelitian ini menggunakan metode Partial Least Squares (PLS) (Ghozali, 2011) PLS merupakan factor indeterminacy model analisis yang powarful, karena tidak mengasumsikan data harus dengan skala tertentu, dan jumlah sampel kecil, dan juga dapat digunakan untuk konfirmasi teori, lebih lanjut (Ghozali, 2011 dalam Yusuf, 2016) PLS membantu peneliti untuk mendapatkan nilai variabel laten untuk tujuan prediksi. Estimasi parameter yang didapat dengan PLS dapat dikategorikan menjadi tiga, meliputi (Ghozali, 2011):

a) Kategori pertama, adalah weight estimate yang digunakan untuk menciptakan skor variabel laten;

b) Kategori kedua, adalah mencerminkan estimasi jalur (path estimate) yang menghubungkan variabel laten dan antara variabel laten dan blok indikatornya (loading); dan

c) Kategori ketiga, berkaitan dengan means dan lokasi parameter (nilai konstanta regresi) untuk indikatordan variabel laten.

Untuk memperoleh ketiga estimasi di atas, PLS menggunakan proses iterasi tiga tahap dan setiap tahap iterasi menghasilkan estimasi. Tahap pertama menghasilkan weight estimate, tahap kedua menghasilkan estimasi untuk inner model dan outer model, dan tahap ketiga munghasilkan estimasi means dan lokasi (konstanta).

\section{HASIL PENELITIAN DAN PEMBAHASAN}

\section{Deskripsi Kuesioner.}

Deskripsi kuesioner seperti terlihat pada Tabel 1 berikut, menggambarkan proses penyebaran dan pengembalian atau penarikan kuesioner, serta penetapan kuesioner final sementara yang digunakan untuk analisis laporan kemajuan penelitian. 
Table 2. Deskripsi Kuesioner Penelitian, 2018

\begin{tabular}{|c|l|c|l|}
\hline 1 & Kuesioner yang diedarkan & 100 & $100 \%$ \\
\hline 2 & $\begin{array}{l}\text { Kuesioner yang dikembalikan yang } \\
\text { rusak/kosong tanpa isi }\end{array}$ & 34 & $68 \%$ \\
\hline 3 & $\begin{array}{l}\text { Kuesioner yang belum dikembalikan atau } \\
\text { hilang }\end{array}$ & 9 & $18 \%$ \\
\hline 4 & $\begin{array}{l}\text { Kuesioner dikembalikan dan dapat } \\
\text { digunakan untuk analisis }\end{array}$ & 57 & $114 \%$ \\
\hline 5 & Kuesioner & $\mathbf{5 7}$ & $114 \%$ \\
\hline
\end{tabular}

Tabel 2 di atas, menggambarkan bahwa terdapat 100 rangkap kuesioner yang diedarkan kepada seluruh responden yang ada di DPRD, Inspektorat Daerah, dan LSM (Yayasan Lendola), adapun kuesioner yang dikembalikan dalam keadaan kosong dan rusak sebayak 34 rangkap kuesioner, serta kuesioner yang belumdikembalikan atau hilang sebayak 9 rangkap kuesioner, sehingga kuesioner yang dikembalikan dan dapat digunakan untuk analisis sebayak 57 rangkap kuesioner.

\section{Deskripsi Statistik}

Deskriptif statistik menggambarkan karakteristik data setiap variabel penelitian, baik penyajian laporan keuangan, aksesibilitas, dan informasi laporan keuangan Kabupaten Alor. Karakteristik data dalam penelitian ini mencakup nilai: minimum, maximum, mean, sum, dan standard deviation (SD) dari setiap variabel penelitian.

Tabel 3. Descriptive Statistics Variabel Penyajian Laporan Keuangan, Aksesibilitas, dan Informasi Laporan Keuangan

\begin{tabular}{|l|r|r|r|r|r|r|}
\hline & \multicolumn{1}{|c|}{$\mathrm{N}$} & Minimum & Maximum & Sum & Mean & Std. Deviation \\
\cline { 2 - 7 } & & & & & & \\
\hline $\mathrm{x} 1$ & 57 & 38 & 70 & 3318 & 58,21 & 8,449 \\
$\mathrm{Y}$ & 57 & 30 & 50 & 2406 & 42,21 & 5,112 \\
$\mathrm{x} 2$ & 57 & 8 & 15 & 682 & 11,96 & 2,009 \\
Valid N & 57 & & & & & \\
(listwise) & & & & & & \\
\hline
\end{tabular}

Tabel 3 di atas, menggambarkan karakteristik data variabel-variabel: Penyajian Laporan Keuangan, Aksesibilitas, dan Informasi Laporan Keuangan. Nilai mean tertinggi terdapat pada variable Penyajian Laporan Keuangan (X1) dengan nilai 58,21. Hal ini dapat dipahami bahwa Penyajian Laporan Keuangan memberikan kontribusi tertinggi terhadap Penggunaan Informasi dan memiliki peran strategis dalam mendorong kinerja pemerintah Kabupaten Alor. Peran strategis yang dimaksud dilakukan melalui keterbukaan pemerintah Kabupaten Alor kepada public sementara, Variabel Aksesibilitas (X2) berkontribusi terhadap penggunaan Informasi Laporan Keuangan pemerintah Kanupaten Alor sebesar 11,96 dan Variabel Informasi Laporan Keuangan (Y) memiliki nilai mean sebesar 42,21 . 


\section{Hasil Uji Simultan (Uji Statistik F)}

Uji F dilakukan untuk menguji apakah variabel penyajian laporan keuangan (X1) danAksesibilitas(X2), secara bersama-sama mempunyai pengaruh yang positif dan signifikan terhadap penggunaan informasi keuangan daerah (Y). Nilai F hitung diperoleh dengan menggunakan alat bantu program statistik seperti terlihatpada tabel 4 Dengan rumus yang digunakan untuk menentukan $\mathrm{F}$ tabel adalah :

Tabel 4. Hasil Uji Simultan (Uji Statistik F) (SmartPLS Versi 3, 2018)

\begin{tabular}{|c|c|c|c|c|c|c|}
\hline \multicolumn{7}{|c|}{ ANOVA $^{a}$} \\
\hline & & $\begin{array}{l}\text { Sum of } \\
\text { Squares }\end{array}$ & df & Mean Square & $\mathrm{F}$ & Sig. \\
\hline \multirow[t]{3}{*}{1} & Regression & 1132.185 & 2 & 566.093 & 92.273 & $.000^{\mathrm{b}}$ \\
\hline & Residual & 331.288 & 54 & 6.135 & & \\
\hline & Total & 1463.474 & 56 & & & \\
\hline
\end{tabular}

Berdasarkan tabel 4 di atas dapat dilihat bahwa dalam pengujian menunjukkan hasil $\mathrm{F}$ hitung sebesar 92,273 dengan signifikan 0,000 yang lebih kecil dari 0,05, maka H0 ditolak dan H1 diterima. Berarti penyajian laporan keuangan daerah dan aksesibilitas laporan keuangan secara bersama-sama berpengaruh positif dan signifikan terhadap penggunaan informasi keuangan daerah.

\section{Uji Outer Model atau Measurement Model}

Outer model dinilai dengan cara melihat convergent validity (besarnya loading factor untuk masing-masing konstruk). Ghozali (2008) suatu indikator dianggap valid jika memiliki nilai korelasi di atas 0,70. Namun untuk loading 0,50 sampai 0,60 masih dapat ditolerir (model dalam tahap pengembangan) dengan melihat output korelasi antara indikator dengan konstruknya. Gambar berikut merupakan hasil Algoritma PLS tahap pertama terhadap konstruk penelitian dan indikatornya.

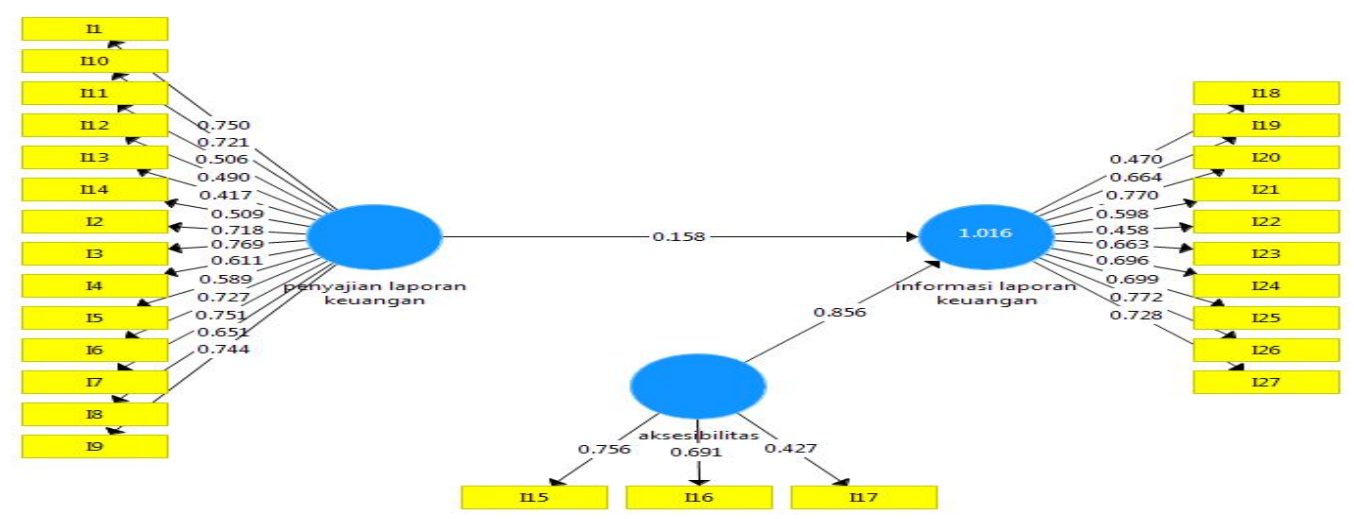

Gambar 1. Hasil Algoritma PLS tahap pertama terhadap konstruk penelitian dan indikatornya (SmartPLS Versi 3, 2018) 
Gambar output di atas menunjukkan bahwa, convergent validity dengan loading factor untuk konstruk Penyajian Laporan Keuangan (Variabel Laten 1) terdapat indicator yang nilainya kurang dari 0,50 yakni indicator $\mathrm{I} 12=0,490$, dan $\mathrm{I} 13=0,417$, Konstruk Aksesibilitas (Variabel Laten 2) terdapat satu indicator yang nilainya kurang dari 0,50, yakni I17 = 0,427, dan Konstruk Informasi Laporan Keuangan (Variabel Laten 3) terdapat dua indicator yang nilainya kurang dari 0,50 yakni indicator I18 $=0,470$, dan I22 $=0,458$. Indicator-indikator tersebut dikeluarkan, kemudian dilakukan Algoritma PLS kedua (re-estimasi), dengan output seperti pada gambar berikut.

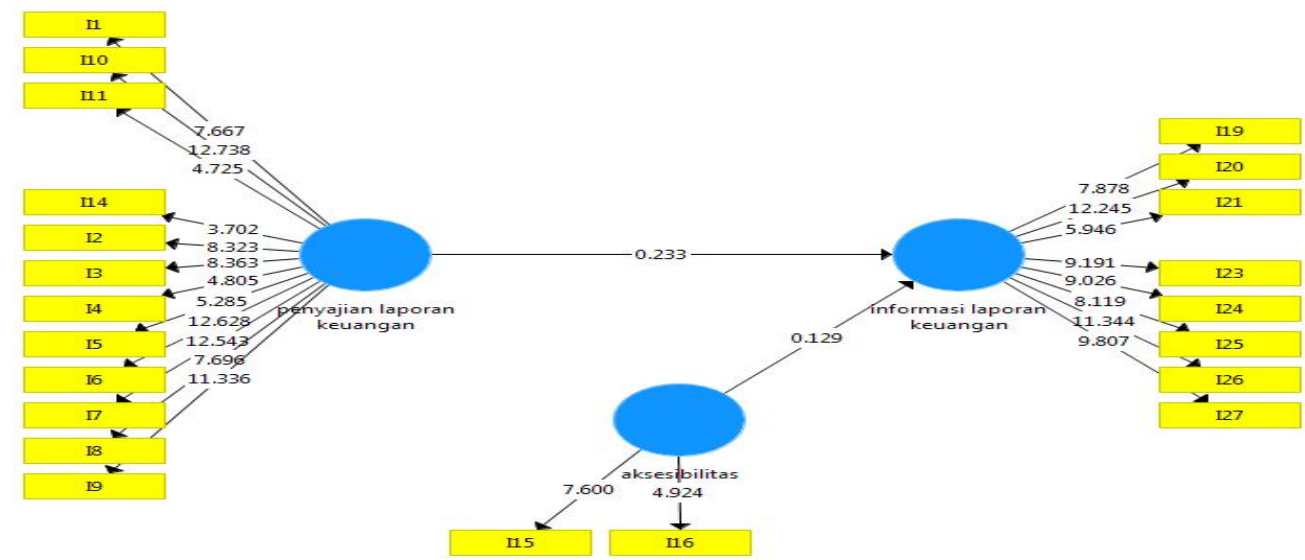

Gambar 2. Algoritma PLS kedua atau re-estimasi(SmartPLS Versi 3, 2018)

Hasil algoritma tahap kedua (re-estimasi) seperti gambar 2 di atas, menunjukkan bahwa keseluruhan indikator baik pada konstruk Penyajian Laporan keuangan, Aksesibilitas, dan Informasi Laporan Keuangan telah memenuhi convergent validity karena semua loadingfactor berada di atas 0.50 .

Uji lainnya adalah composit reliability dari blok indikator yang mengukur konstruk, seperti terlihat pada tabel berikut. Reliabilitas masing-masing konstruk yang digunakan dalam penelitian ini dapat dilihat melalui composite reliability dan cronbach alpha pada tabel 5, dengan nilai yang dipersyaratkan $>0.70$. Tabel tersebut dapat dilihat bahwa, composite reliability dan cronbach alpha keempat konstruk cukup tinggi di atas 0.70 .

Tabel 5. Validitas dan Reliabilitas Konstruk (SmartPLS Versi 3, 2018)

\begin{tabular}{|c|c|c|c|c|c|c|c|c|c|c|}
\hline \multirow[t]{2}{*}{ 固 } & \multirow[t]{2}{*}{ Matriks } & \multirow[t]{2}{*}{ 掉萃 } & Cronbach's Alpha & 拹虽 & rho_A & 掉费 & \multicolumn{2}{|c|}{ Reliabilitas Komposit } & \multicolumn{2}{|c|}{ Rata-rata $V_{i}$} \\
\hline & & & \multicolumn{2}{|l|}{ Cronbach's Al... } & \multicolumn{2}{|c|}{ rho_A } & Reliabilitas Ko... & \multicolumn{3}{|c|}{ Rata-rata Varia... } \\
\hline \multicolumn{3}{|c|}{ aksesibilitas } & 0.582 & & \multicolumn{2}{|c|}{0.589} & 0.585 & & & 0.414 \\
\hline \multicolumn{3}{|c|}{ informasi lapor... } & 0.888 & & \multicolumn{2}{|c|}{0.891} & 0.889 & & & 0.501 \\
\hline \multicolumn{3}{|c|}{ penyajian lapor... } & 0.905 & & \multicolumn{2}{|c|}{0.915} & 0.907 & & & 0.454 \\
\hline
\end{tabular}




\section{Uji Inner Model atau Model Struktural}

Pengujian inner model akan memberikan hasil hubungan antar konstruk. Tabel 6 berikut merupakan hasil bootstrapping yang menggambarkan hasil estimasi masingmasing konstruk signifikansi 5\% (T-Statistik > 1.96), seperti terlihat pada tabel 6 .

Tabel 6. Path Coefficients (Mean, STDEV, T-Values, P-Values) (SmartPLS Versi 3, 2018)

\begin{tabular}{|c|c|c|c|c|c|}
\hline & Sampel Asli (0) & Sample Mean (... & Standar Devias... & T Statistik (| $0 / \ldots$ & PValues \\
\hline aksesibilitas -> ... & 0.334 & 0.330 & 0.099 & 3,390 & 0.001 \\
\hline penyajian lapor... & 0.625 & 0.636 & 0.089 & 7.027 & 0.000 \\
\hline
\end{tabular}

Tabel 6 di atas menunjukkan bahwa haya terdapat dua hipotesis yang dapat di terima yakni aksesibilitas dan informasi laporan keuangan. Pada baris pertama, menunjukkan bahwa hubungan antara Aksesibilitas dengan Informasi laporan keuangan adalah signifikan dengan T-Statistik sebesar 3,390 (> 1,96) dan nilai koefisien 0,334. Dengan demikian Hipotesis H1 dalam penelitian ini yang menyatakan bahwa aksesibilitas berhubungan positif dengan Informasi laporan keuangan dapat diterima. Begitu pula pada baris ke dua, hubungan antara Penyajian laporan keuangan dengan Informasi laporan keuangan adalah signifikan dengan T-statistik sebesar 7,027 (>1,96) dan nilai koefisien 0,625, sehingga Hipotesis $\mathrm{H} 2$ yang meyatakan bahwa Penyajian Laporan Keuangan berhubungan positif dengan Informasi laporan keuangan dapat diterima.

Gambar 3 berikut, ditampilkan secara lengkap hasil bootstrapping yang menggambarkan hubungan antara konstruk dan nilai $\mathrm{T}$ statistic berdasarkan output SmartPLS Versi 3:

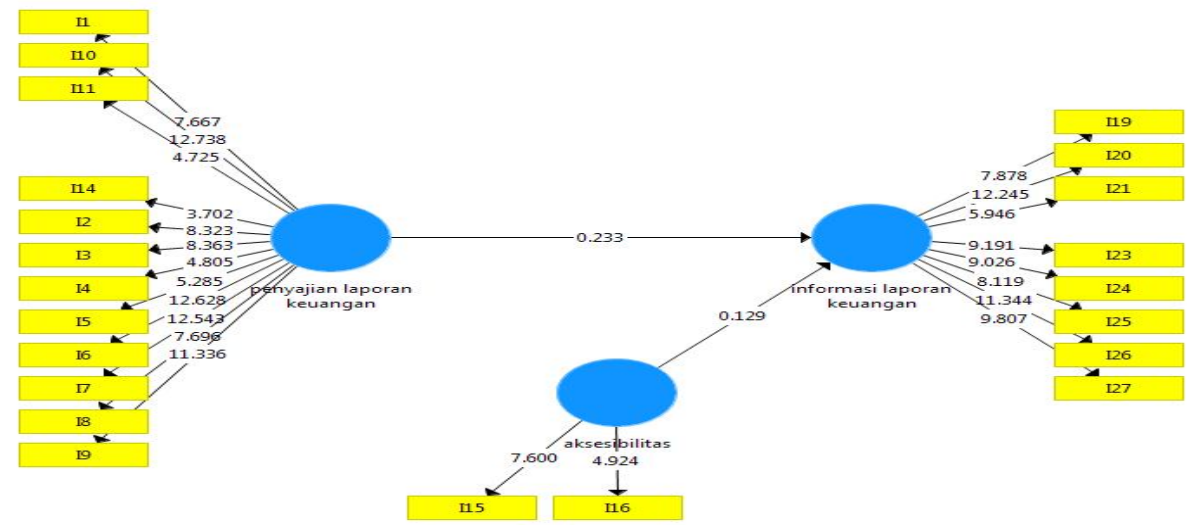

Gambar 3: $\quad$ Hasil bootstrapping hubungan antara konstruk dan nilai $\mathrm{T}$ statistic (SmartPLS Versi 3, 2018)

\section{PEMBAHASAN}

Pembahasan hasil penelitian ini dibagi menjadi dua bagian sesuai tujuan penelitian dan hipotesis penelitian, yakni: Hubungan Penyajian Laporan Keuangan dengan Informasi Laporan Keuangan, Hubungan Aksesibilitas dengan Informasi 
Laporan Keuangan dengan mengacu pada hasil uji hupotesis menggunakan SmartPLS Versi 3.

\section{a. Pengaruh Penyajian Laporan Keuangan Daerah Terhadap Penggunaan Informasi Keuangan Daerah}

Hasil uji inner model menunjukkan bahwa hubungan antara Penyajian Laporan Keuangan dengan Informasi Laporan Keuangan adalah signifikan dengan nilai koefisien sebesar 0,625 sehingga hasil studi ini menerima hipotesis pertama (H1) yaitu penyajian laporan keuangan daerah berpengaruh positif dan signifikan terhadap penggunaan informasi keuangan daerah, maka hasil yang diperoleh adalah hipotesis pertama diterima. Hasil penelitian ini menunjukan bahwa dengan meningkatnya frekuensi penyajian laporan keuangan daerah maka akan berimplikasi terhadap peningkatan penggunaan informasi keuangan daerah oleh para pengguna laporan keuangan. Dalam penelitian ini dikatakan bahwa ketika entitas pemerintah menyajikan laporan keuangan dengan baik maka hal tersebut dapat dinikmati atau dipergunakan oleh para pengguna informasi keuangan. Ketika informasi keuangan pemerintah telah dipergunakan oleh para pengguna laporan keuangan maka laporan keuangan tersebut bisa dinilai transparansi dan akuntabilitasnya oleh para pengguna laporan keuangan. Berarti laporan keuangan pemerintah telah mampu dipertanggungjawabkan kepada para pengguna laporan keuangan.

\section{b. Pengaruh Aksesibilitas Laporan Keuangan Terhadap Penggunaan Informasi Keuangan Daerah.}

Hasil uji inner model menunjukkan bahwa hubungan antara Aksesibilitas dengan Informasi Laporan Keuangan adalah signifikan dengan nilai koefisien sebesar 0,334 sehingga hasil studi ini menerima hipotesis kedua (H2) yaitu pengaruh akasesibilitasterhadap penggunaan informasi laporan keuangan daerah maka dapat dikatakan bahwa, semakin baik akses yang diberikan oleh pihak pemerintah kepada pihak pengguna informasi keuangan maka akan semakin baik pula informasi tersebut dapat digunakan. Hal ini menunjukan bahwa ketika pemerintah memberikan akses kepada publik maka pemerintah memilki tanggung jawab kepada publik untuk memberikan kumudahan dalam hal pengaksesan laporan keuangan.

\section{E. KESIMPULAN DAN SARAN}

\section{Kesimpuan}

Berdasarkan hasil uji hipotesis dengan pendekatan Partial Least Square (PLS) dengan aplikasi SmartPLS Versi 3 yang disajikan sebelumnya, maka dapat disimpulkan bahwa, pengaruh penyajian laporan keuangan daerah dan aksesibilitas terhadap penggunaan informasi laporan keuangan daerah. Penyajian laporan keuangan yang lengkap dan secara langsung tersedia dan aksesibel bagi pengguna informasi menentukan sejauh mana keterbukaan pemerintah kepada publik melalui penyajian laporan keuangan daerah terhadap penggunaan informasi laporan keuangan daerah. dan aksesibilitas pengelolaan keuangan daerah terhadap informasi keuangan daerah tersebut. Adapun kesimpulan dari hasil penelitian adalah sebagai berikut :

a) Penyajian laporan keuangan daerah berpengaruh positif dan signifikan terhadap informasi laporan keuangan daerah;dan

b) Aksesibilitas berpengaruh positif dan signifikan terhadap informasi laporan keuangan daerah. 


\section{Saran}

Berdasarkan hasil penelitian, pembahasan dan kesimpulan yang telah diambil di atas, maka dapat diberikan saran sebagai berikut:

a) Untuk penelitian selanjutnya, sebaiknya lebih memperluas lagi sampel penelitian yaitu dengan mengambil sampel dari SKPD sebagai penyaji laporan keuangan agar data yang diperoleh dapat dibandingkan antara pengguna internal dengan pengguna eksternal laporan keuangan;

b) Untuk penelitian selanjutnya, sebaiknya lebih memperluas lagi sampel penelitian. Terutama untuk sampel yang mewakili masyarakat, diharapkan tidak hanya LSM saja yang menjadi sampel penelitian, melainkan misalnya dari pihak pers atau lembaga-lembaga keuangan;

c) Peneliti yang akan datang agar memperluas variabel yang diteliti, selain variabel yang diteliti sekarang; dan

d) Peneliti yang akan datang juga dapat menggunakan metode interview selain dengan kusioner untuk mendapatkan data yang lebih kredibel.

\section{DAFTAR PUSTAKA}

Bandariy, Himmah. Pengaruh PenyajianLaporan Keuangan Daerah Dan Aksesibilitas Laporan Keuangan Terhadap Penggunaan Informasi Keuangan Daerah (Studi Pada Kabupaten Eks Karesidenan Banyumas) Universitas Diponegoro Semarang. 2011, pp. 1-28.

Christy Natalia Lewier, Ch.Heni Kurniawan, and Program. Pengaruh Penyajian Laporan Keuangan Daerah Dan Aksesibilitas Laporan Keuangan Daerah Terhadap Akuntabilitas Pengelolaan Keuangan Daerah Kabupaten Klanten. Vol. 3, no. 3, 2012, p. 56, doi:10.4135/9781412950589.n774.

Daerah, Keuangan, and Lila Anggraini. Pengaruh Penyajian Laporan Keuangan Daerah

Dan Aksesibilitas Terhadap Penggunaan Informasi Keuangan Daerah (Studi Pada

Provinsi Riau) Yesi. Vol. 1, no. 2, 2014, pp. 1-15.

Ekonomi, Fakultas, and Universitas Diponegoro. 1 Waode\%20Alnur\%20Mulia. 2011.

Febrianti Sukma.Analisis Pengaruh Penatausahaan Aset Tetap Terhadap Kualitas Laporan Keuangan Pemerintah Daerah Kabupaten Kubu Raya. Vol. 10, no. 1, 2016.

Ghozali, Imam. Aplikasi Analisis Multivariate dengan program SPSS. Tegal: Penerbit Universitas Diponegoro. 20011

Gozali, Imam. Structural Equation Modeling Metode Alternatif dengan Partial Least Square (PLS). Semarang: Penerbit Universitas Diponegoro. 2011

Hehanussa, Salomi J. Pengaruh Penyajian Laporan Keuangan Daerah Dan Aksesibilitas Laporan Keuangan Daerah Terhadap Transparansi Dan Akuntabilitas Pengelolaan Keuangan Daerah Kota Ambon Salomi. Vol. 2, 2015, pp. 82-90.

Mardiasmo. 2002. Akuntansi Sektor Publik. Yogyakarta: Penerbit ANDI.

Mulyana, Budi. "Pengaruh Penyajian Neraca Daerah dan Aksesibilitas Laporan Keuangan terhadap Transparansi dan Akuntabilitas Pengelolaan Keuangan Daerah". Jurnal Akuntansi Pemerintahan Vol.2 No. 1. (2006). h. 1-21.

Nurlaili. "Pengaruh Penyajian Laporan Keuangan Dan AksesibilitaS Laporan Keuangan 
Terhadap Akuntabilitas Pengelolaan Keuangan Daerah (Studi Pada SKPD Kabupaten Bengkalis) Effect Of Financial Statements Presentation Of Financial Statements And Accessibility Of Region.” JOM Fekon, vol. 3, no. 1, 2016.

Oktora, Fahri Eka, and Winston Pontoh. "Analisis Hubungan Pendapatan Asli Daerah,

Dana Alokasi Umum, Dan Dana Alokasi Khusus Atas Belanja Modal Pada

Pemerintah Daerah Kabupaten Tolitoli Provinsi Sulawesi Tengah.” Jurnal Accountability, vol. 2, no. 1, 2013, pp. 1-10.

"Pengaruh Penyajian Dan Aksesibilitas Laporan Keuangan Terhadap Akuntabilitas

Pengelolaan Keuangan Daerah (Survey Pada Seluruh Dinas Pemerintahan Kota

Bandung) Hani." Hani Nurhayani Jurusan.

Ramadhani, Yesi, dkk. "Pengaruh Penyajian Laporan Keuangan Daerah Dan

Aksesibilitas Terhadap Penggunaan Informasi Keuangan Daerah (Study Pada

Provinsi Riau)". Jom Fekon Vol. 1. no. 2. (2014) h 1-15

Rika Wulandari. "Pengaruh Akuntabilitas Laporan Keuangan Pemerintah Daerah (LKPD)

Dan Kinerja Keuangan Pemerintah Daerah Terhadap Tingkat Korupsi Pemerintah

Daerah Di Indonesia.” Rika Wulandari, 2015.

Sande Peggy. Pengaruh Penyajian Laporan Keuangan dan Aksesibilitas Laporan Keuangan Terhadap Akuntabilitas Pengelolaan Keuangan Daerah. Jurnal Akuntansi. Vol.

1. No. 1. (2013)

Saputra, Ardi Rahmawan. "Kajian Penggunaan Informasi Keuangan Daerah”. Accounting Analysis Journal. Vol 1. No. 2 (2012) h 1-6

Siti Aliyah, and Aida Nahar. "Pengaruh Penyajian Laporan Keuangan Daerah Dan Aksesibilitas Laporan Keuangan Daerah Terhadap Transparansi Dan Akuntabilitas

Pengelolaan Keuangan Daerah Kabupaten Jepara." Jurnal Akuntansi \& Auditing, vol. 8, no. 2, 2012, pp. 137-50.

Supriyanto, 2011, Akuntansi Perpajakan, Edisi Pertama, Graha Ilmu, Yogyakarta.

Sugiyono, 2012, Metode Penelitian Kuantitatif Kualitatif, Dan R \& D, Alvabeta, Bandung.

Wahida, N. "Pengaruh Penyajian Laporan Keuangan Daerah Dan Aksesibilitas Laporan

Keuangan Daerah Terhadap Transpransi Dan Akuntabilitas Pengelolaan Keuangan Daerah Kabupaten Jepara.” Jurnal Akuntansi \& Auditing, vol. 8, no. 2, 2012, pp. 137-50.

Wahyuni, Putu Sri, et al. Pengaruh Penyajian Laporan Keuangan Daerah Dan Aksesibilitas Laporan Keuangan Daerah Terhadap Akuntabilitas Pengelolaan Keuangan Daerah( Studi Empiris Pada Pemerintahan Kabupaten Badung ) Jurusan Akuntansi Program S1. Vol. 2, no. 1, 2014. 